
RESEARCH AND DEVELOPMENT

\author{
http://journal.unnes.ac.id/sju/index.php/higeia
}

\title{
Youth Centre Model Peningkatan Pengetahuan dan Sikap Remaja di Daerah Tinggi Kehamilan Berisiko
}

\author{
Muhammad Azinar $^{1 凶}$, Arulita Ika Fibriana $^{1}$ \\ ${ }^{1}$ Jurusan Ilmu Kesehatan Masyarakat, Fakultas Ilmu Keolahragaan, Universitas Negeri Semarang, Indonesia
}

\begin{abstract}
Info Artikel
Sejarah Artikel:

Diterima 18 September

2018

Disetujui 17 Oktober

2018

Dipublikasikan 30

Oktober 2018

Keywords:

Youth Centre, Knowledge,

Atitude, Risky Pregnancy

\section{DOI:}

https://doi.org/10.15294

Abstrak

Jumlah kasus kematian ibu di kabupaten Kendal pada tahun 2015 sebanyak 23 kasus, tahun 2016 19 kasus, dan tahun 2017 naik menjadi 25 kasus. Desa Singorojo adalah desa yang dalam 3 tahun terakhir memiliki trend kenaikan kasus kehamilan risiko tinggi yang signifikan. Penelitian ini bertujuan untuk mengetahui efektivitas Youth Centre Model dalam meningkatkan pengetahuan sikap remaja di daerah kehamilan berisiko tinggi. Penelitian ini dirancang dengan desain pre-eksperimental research dengan one group pretest-posttest design yang dianalisis secara kuantitatif. Populasi penelitian adalah remaja di desa Singorojo kabupaten Kendal. Sampel ditentukan secara purposive sampling. Analisis data dilakukan dengan menggunakan uji beda dan uji Wilcoxon. Hasil penelitian menujukkan edukasi sebaya yang dilakukan oleh Kader Youth Centre yang telah diberi pelatihan telah mampu meningkatkan pengetahuan kesehatan reproduksi remaja khususnya terkait seksualitas dan kehamilan berisiko tinggi ( $p$ value 0,001 ). Selain itu juga dapat meningkatkan kesadaran remaja akan pentingnya pendewasaan usia perkawinan melalui perubahan sikap remaja ( $p$ value 0,002). Simpulan menunjukkan Youth Centre dapat meningkatkan pengetahuan dan kesadaran pada siswa remaja.
\end{abstract}

/higeia.v2i4.26801

\begin{abstract}
The number of maternal mortality cases in Kendal district in 2015 reached 23 cases, in 2016 were 19 cases, and in 2017 were 25 cases. Singorojo village was a village that in the last 3 years had a significant upward trend in cases. This study aimed to determine the effectiveness of the Youth Center Model in increasing the knowledge of the attitudes of adolescents in high risk pregnancy areas. This study was designed with a preexperimental research design with one pretest-posttest design group analyzed quantitatively. The study population was adolescents in Singorojo village, Kendal district. Sampling technique used purposive sampling. Data analysis was used a different test and Wilcoxon test. The results of a complete peer education study conducted by Youth Center Cadres who had been given training had been able to improve adolescent health knowledge with high sexuality and pregnancy ( $p$ value 0.001 ). In addition, it could also increase teenagers' awareness of the importance of marriage awareness for adolescent girls ( $p$ value 0.002). Conclusion showed that Youth Center can increase knowledge and awareness of adolescent students.
\end{abstract}

(C) 2018 Universitas Negeri Semarang

$\triangle$ Alamat korespondensi:

Gedung F5 Lantai 2 FIK Unnes

p ISSN 1475-362846

Kampus Sekaran, Gunungpati, Semarang, 50229

e ISSN 1475-222656

E-mail: azinar.ikm@mail.unnes.ac.id 


\section{PENDAHULUAN}

Kematian ibu baik pada masa kehamilan dan persalinan masih menjadi masalah besar di Indonesia. Target MDGs dalam menurunkan angka kematian ibu (AKI) menjadi 102/100.000 kelahiran hidup sampai berakhirnya MDGs tahun 2015 belum dapat tercapai. AKI di Jawa Tengah juga masih besar yaitu 111,16 per 100.000 kelahiran hidup (Dinkes Jateng, 2017). Demikian juga di kabupaten Kendal, jumlah kasus kematian ibu masih cukup tinggi. Pada tahun 2015 adalah terjadi 23 kasus, tahun 2016 terjadi 19 kasus, dan tahun 2017 naik menjadi 25 kasus (Dinkes Kendal, 2018).

Penyebab utama kasus kematian ibu adalah perdarahan, hipertensi dan anemia $(\mathrm{Hb}<10 \mathrm{~g} / \mathrm{dl}) . \quad$ Komplikasi kehamilan, komplikasi persalinan, dan riwayat penyakit ibu hamil menjadi determinan utama kasus kematian ibu (Aeni, 2013; Kaddour et al, 2008). Selain itu, riwayat penyakit ibu juga dapat meningkatkan risiko kematian ibu (Bazaar, dan Azhari, 2012).

Kondisi "3 terlambat", yaitu terlambat dalam pengambilan keputusan, terlambat mencapai tempat rujukan, serta terlambat dalam mendapatkan pertolongan yang tepat di fasilitas kesehatan, menjadi faktor risiko kematian ibu. Selain itu, kondisi ibu hamil dalam kategori " 4 terlalu" yaitu terlalu tua, terlalu muda saat melahirkan, terlalu sering melahirkan dan terlalu rapat jarak kelahiran satu dengan berikutnya juga menjadi faktor risiko kematian ibu (Dinkes Kendal, 2017).

Letak geografis wilayah Singorojo dan kondisi sosiokultural pedesaan, turut menjadi faktor risiko kematian ibu. Jarak menuju pusat layanan rujukan persalinan yang jauh menjadi penyebab semakin tingginya risiko kematian ibu khususnya pada masa persalinan. Masyarakat harus menempuh jarak lebih dari 33 kilometer untuk dapat mengakses layanan rujukan komplikasi kehamilan maupun persalinan di rumah sakit (Dinkes Kendal, 2017).

Wilayah Puskesmas Singorojo I merupakan wilayah yang dalam tiga tahun terakhir mengalami peningkatan jumlah kasus kehamilan berisiko tinggi. Data Puskesmas Singorojo I menunjukkan pada tahun 2015 persentase kehamilan risiko tinggi mencapai 37,5\%. Pada tahun 2016 persentase tersebut naik secara signifikan yaitu menjadi 58,9\%. Kasus tersebut belum bisa ditekan sampai saat ini. Persentase kehamilan berisiko tinggi masih tinggi yaitu $58,17 \%$.

Desa Singorojo adalah desa yang dalam 3 tahun terakhir memiliki trend kenaikan kasus kehamilan risiko tinggi yang signifikan. Pada tahun 2015 yaitu 36,25\% kehamilan yang terjadi adalah kehamilan berisiko tinggi, naik menjadi 39,24\% pada tahun 2016 dan naik drastis pada tahun 2017 yaitu menjadi 55,42\% (Puskesmas Singorojo I, 2018). Fakta-fakta ini menunjukkan bahwa kehamilan yang terjadi di wilayah tersebut sebagian besar adalah kehamilan berisiko tinggi. Kondisi ini akan berdampak serius termasuk terjadinya komplikasi persalinan bahkan dapat berdampak fatal pada kemungkinan terjadinya kasus kematian ibu.

Studi awal yang dilakukan oleh Tim Pengabdi awal Februari 2018, mendapatkan fakta bahwa kehamilan risiko tinggi di wilayah tersebut banyak disebabkan oleh faktor usia ibu hamil. Kehamilan dan persalinan usia muda masih banyak terjadi di wilayah tersebut. Data Bidan Desa setempat menunjukkan 67\% kehamilan yang terjadi di wilayah tersebut adalah kehamilan pada usia muda (kurang dari 20 tahun) dan sebagian besar adalah kehamilan dan persalinan yang tidak direncanakan secara matang. Kondisi ini selain menyebabkan jumlah kelahiran yang dialami oleh ibu usia muda akan lebih banyak atau lebih sering, juga akan menjadi faktor risiko gangguan kehamilan dan komplikasi persalinan.

Faktor-faktor internal meliputi intensitas komitmen kedua pasangan untuk menjalin hubungan jangka panjang dalam perkawinan, sikap dan persepsi terhadap janin yang dikandung, dan persepsi subjektif tentang kesiapan psikologis dan ekonomi untuk memasuki kehidupan perkawinan. Faktor-faktor ekstemal meliputi sikap dan penerimaan orangtua kedua belah pihak, penilaian socially constructed perception, nilai-nilai normatif dan etis 
dari lembaga keagamaan, dan kemungkinankemungkinan perubahan hidup pada masadepanyangmengikutipelaksanaan suatu keputusanyang akan dipilih. Bagi remaja yang mengalaminya, kehamilan pranikah memunculkan dilema kemanusiaan yang paling dasar, yang menyangkut pertanyaan tentang hak hidup calon mahluk manusia dilawankan dengan pertimbanganpertimbangan ekstemal yang sangat kompleks.

Dari hasil wawancara mendalam terdahulu diketahui bahwa remaja yang baru mengetahui dirinya hamil memberikan reaksi awal yang hampir serupa rasa relatif aman yang selama ini dirasakannya karena orang lain dan masyarakat tidak mengetahui bahwa ia telah melakukan hubungan seks pranikah, tiba-tiba bukan lagi merupakan alasan. Kengerian akan sanksi sosial berupa pengucilan dan pelecehan sosial yang amat berat tiba-tiba saja hadir kongkret dihadapannya. Berbagai kecemasan tentang konsekuensi lanjutan dari kehamilanpranikah menjadi nightmare baginya: "Bagaimana perasaan dan sikap orang tuaku bila mereka tahu?

Bagaimana kalau pacarku tahu,apakah iaakan meninggalkanku?Apa pendapat masyarakat nanti? Bagaimana dengan sekolah dan kuliahku? Apa yang akan dikatakan temanteman nanti? Bagaimanastatus anakku kelak? Seperti apa rasa sakitnya melahirkan? Bagaimana anakku akan kuurus sementara aku belum siap secara ekonomi? Apa yang harus kulakukan. aborsi atau meneruskan kehamilan?"

Pengetahuan kesehatan reproduksi yang masih rendah dari remaja khususnya, menjadi salah satu penyebab utama terjadinya perkawinan usia dini. Akibatnya perkawinan tersebut banyak yang tidak direncanakan secara baik dan matang. SDKI (2007) menyebutkan pengetahuan remaja tentang kesehatan reproduksi remaja masih rendah dan median usia kawin pertama perempuan relatif masih rendah yaitu 19,8 tahun. Hal ini menjadi permasalahan yang vital yang dihadapi remaja saat ini khususnya di daerah-daerah pedesaan.

Reproduksi adalah fungsi yang dianggap dasariah, terhormat, dan bahkan sakral. Akan tetapi, peristiwa ini kerap terjadi terlalu awal dalam siklus kehidupan seseorang, tanpa dikehendaki, terlalu sering, atau terjadi dalam keadaan yang tidak tepat. Kehamilanyang bukan merupakan hasil keputusan dari pilihan bebas akan menjadi kemelut individu dan drama keluarga yang pahit ketika dialami oleh remaja yang belum menikah. Pasangan remaja dan keluarganya dihadapkan pada pilihan-pilihan yang sangat dilematis dalam mencari jalan keluar. Mereka dihadapkan pada proses

pengambilan keputusan yang rumit, yang melibatkan dua jenis pertimbangan, yakni pertimbangan faktor-faktor internal dan pertimbanganfaktor-faktor ekstemal.

Remaja perempuan harus disiapkan secara matang untuk menghadapi proses reproduksi yang aman dan sehat. Perkawinan, kehamilan dan persalinan wajib dipersiapkan dan direncanakan secara matang. Oleh karena itu, remaja khususnya remaja perempuan sangat perlu diintervensi secara komprehensif khususnya dalam mengenali kesehatan reproduksi, permasalahannya, faktor risiko dan dampak-dampak yang mungkin dihadapi selama masa reproduksinya serta bagaimana upaya penanggulangan dan pencegahannya.

Pemberdayaan dan pembinaan remaja terutama untuk menciptakan remaja sehat reproduksi belum banyak dilakukan di daerahdaerah pedesaan yang rawan kehamilan risiko tinggi. Salah satu inovasi yang dapat diterapkan adalah dengan membentuk Youth Centre sebagai media edukasi dan promosi pentingnya kesehatan reproduksi pada remaja, dampak perkawinan usia muda serta upaya preventif terhadap kehamilan berisiko tinggi. Belum ada penelitian sebelumnya yang meneliti Youth Centre secara komprehensif, sehingga penelitian ini bertujuan untuk mengetahui perbedaan pengetahuan remaja sasaran antara sebelum dan sesudah diterapkannya Program Youth Centre.

\section{METODE}

Penelitian ini dirancang dengan desain pre-eksperimental research dengan one group pretest- 
posttest design yang dianalisis secara kuantitatif. Instrumen penelitian yaitu dengan memberikan kuesioner pretest dan posttest untuk mengetahui perbedaan signifikan antara pengetahuan sebelum dan sesudah pelatihan. Penelitian ini dimaksudkan untuk mengetahui perbedaan pengetahuan kader sebaya pengelola Youth Centre dan pengetahuan remaja sasaran Youth Centre, keterampilan kader sebaya dalam melakukan edukasi sebaya dan sikap remaja asaran Youth Centre di daerah tinggi kehamilan berisiko sebelum dan sesudah edukasi dan program Youth Centre.

Penelitian ini dilakukan di desa Singorojo kabupaten Kendal. Populasi penelitian adalah remaja di desa Singorojo kabupaten Kendal. Sampel ditentukan dengan cara purposive sampling. Pada penelitian ini, teknik pengambilan sampel tidak berdasarkan random, daerah, atau strata, melainkan berdasarkan atas adanya pertimbangan atau kriteria yang berfokus pada tujuan atau masalah dalam penelitian dalam sebuah populasi. Sample penelitian yang telah dipilih akan mengikuti pretest dan posttest.

Analisis data dilakukan dengan menggunakan uji beda dan uji Wilcoxon. Uji beda adalah bentuk analisis variabel (data) untuk mengetahui perbedaan diantara dua kelompok data (variabel) atau lebih. Kemudian, Uji Wilcoxon digunakan untuk menganalisis hasil-hasil pengamatan yang berpasangan dari dua data apakah data tersebut berbeda atau tidak. Wilcoxon signed Rank test ini digunakan hanya untuk data bertipe interval atau ratio, namun datanya tidak mengikuti distribusi normal.

Teknik pengumpulan data dalam penelitian ini menggunakan kuesioner pretest dan posttest yang berkaitan dengan terkaitan kesehatan reproduksi, seksualitas kehamilan berisiko dan dampak yang dapat ditimbulkan akibat perilaku negatif remaja. Sumber data yang dikumpulkan bersifat primer. Data primer dalam penelitian ini diperoleh dengan hasil pretest dan posttest kepada peserta atau sampel penelitian yaitu para remaja di desa Singorojo kabupaten Kendal.
Penelitian ini dilakukan dalam beberapa tahap yaitu pretest, penyuluhan atau edukasi, postest. Materi penyuluhan berupa materi tentang kesehatan reproduksi remaja khususnya materi seksualitas remaja dan dampak yang dapat ditimbulkan akibat perilaku negatif remaja. Media yang digunakan dalam penyuluhan ini yaitu berupa handout materi untuk mempermudah pemahaman peserta penyuluhan terhadap isi penyuluhan. Kuesioner pretest dan posttest diisi langsung oleh peserta penyuluhan.

Penelitian ini diawali dengan pretest untuk mengetahui sejauh mana tingkat pengetahuan tentang kesehatan reproduksi, seksualitas dan kehamilan berisiko. Jumlah sample penelitian pretest dan posttest berjumlah 13 peserta dan akan didapatkan nilai dari pretest. Analisis data dilakukan dengan menggunakan uji beda dan uji Wilcoxon. Dimaksudkan untuk mengetahui perbedaan pengetahuan antara sebelum dan sesudah pelatihan Kader Sebaya Pengelola Youth Centre.

Setelah diberikan pelatihan sebaya oleh Kader Youth Centre selama 3 kali tatap muka remaja peserta pelatihan diberikan posttest. Sehingga akan di dapatkan skor perbedaan untuk mengetahui perbedaan pengetahuan antara sebelum dan sesudah pelatihan, Setelah didapatkan skor, data kembali dianalisis secara statistik dengan menggunakan uji Wilcoxon.

Selanjutnya, setelah diberikan pelatihan Youth Centre Kesehatan Reproduksi, Kader Sebaya mulai mencoba melaksanakan edukasi kepada remaja sasaran melalui kegiatan Karang Taruna di desa Singorojo. Jumlah sample penelitian berjumlah 29 orang remaja yang mengikuti edukasi. Data dianalisis secara statistik dengan menggunakan uji Wilcoxon.

\section{HASIL DAN PEMBAHASAN}

Evaluasi untuk mengetahui tingkat keberhasilan Program Youth Centre di daerah tinggi kehamilan berisiko dilakukan dengan beberapa indikator yaitu: 1) pengetahuan kader sebaya pengelola Youth Centre, 2) keterampilan kader sebaya dalam melakukan edukasi sebaya, 
Tabel 1. Perbedaan Hasil Pre Test dan Post Test Kader Sebaya Pengelola Youth Centre

\begin{tabular}{|c|c|c|c|c|}
\hline No. & Nama & $\begin{array}{l}\text { Skor } \\
\text { Pre-Test }\end{array}$ & $\begin{array}{l}\text { Skor } \\
\text { Post-Test }\end{array}$ & Selisih \\
\hline 1. & Peserta 1 & 60.0 & 77.5 & 17.5 \\
\hline 2. & Peserta 2 & 47.5 & 67.5 & 20.0 \\
\hline 3. & Peserta 3 & 40.0 & 70.0 & 30.0 \\
\hline 4. & Peserta 4 & 40.0 & 82.5 & 42.5 \\
\hline 5. & Peserta 5 & 52.5 & 80.0 & 27.5 \\
\hline 6. & Peserta 6 & 67.5 & 82.5 & 15.0 \\
\hline 7. & Peserta 7 & 57.5 & 87.5 & 30.0 \\
\hline 8. & Peserta 8 & 62.5 & 82.5 & 20.0 \\
\hline 9. & Peserta 9 & 72.5 & 95.0 & 22.5 \\
\hline 10. & Peserta 10 & 52.5 & 70.0 & 17.5 \\
\hline 11. & Peserta 11 & 52.5 & 80.0 & 27.5 \\
\hline 12. & Peserta 12 & 50.0 & 77.5 & 27.5 \\
\hline \multirow[t]{3}{*}{13.} & Peserta 13 & 65.0 & 80.0 & 15.0 \\
\hline & Rata-rata & 55.38 & 79.42 & \\
\hline & $P$ value & 0.0001 & & \\
\hline
\end{tabular}

3) kegiatan Youth Centre, 4) Pengetahuan remaja sasaran Youth Centre, dan 5) sikap remaja sasaran Youth Centre.

Berdasarkan evaluasi terhadap hasil pretest dan post-test pengetahuan Kader Sebaya Pengelola Youth terkait materi seksualitas remaja diketahui mengalami peningkatan. Hal ini ditunjukkan dengan perbedaan skor pengetahuan antara sebelum dan sesudah pelatihan Kader Sebaya Pengelola Youth Centre.

Tabel 1 menunjukkan terdapat perbedaan signifikan antara pengetahuan sebelum dan sesudah pelatihan. Setelah pelatihan skor pengetahuan meningkat signifikan. Rata-rata skor sebelum pelatihan adalah 55.38 dan meningkat menjadi 79.42 setelah diberi pelatihan ( $p$ value 0,0001$)$.

Selain itu, berdasarkan hasil simulasi setelah pelatihan Kader Sebaya Pengelola Youth Centre, Kader yang dilatih telah mampu mempraktikkan edukasi kesehatan reproduksi remaja khususnya materi seksualitas remaja dengan menggunakan materi yang diberikan oleh fasilitator dengan sasaran teman peserta pelatihan lainnya.

Berdasarkan hasil monitoring, Kader Youth Centre yang telah dilatih telah mampu mempraktikkan edukasi dan konseling sebaya yaitu dengan cara memberikan kasus yang dihadapi remaja dan Kader Sebaya yang dilatih mencoba memberikan solusi atas kasus tersebut. Kader Sebaya mulai terampil dalam memberikan konseling sebaya kesehatan reproduksi remaja. Konseling yang dilakukan adalah seputar kesehatan reproduksi remaja dan dampak yang dapat ditimbulkan akibat perilaku negatif remaja. Diharapkannya dapat tersambungnya pengetahuan dari kader Youth Center kepada remaja dan selanjutnya remaja dapat menyebarluaskan kembali kepada sesama temannya. Sehingga edukasi dan konseling yang telah dilakukan dapat mencapai hasil yang maksimal dengan tersebarluasnya pengetahuan yang diberikan.

Istilah gelanggang remaja merupakan terjemahan dar istilah Bahasa Inggris, Youth Centre. Kata gelanggang mengandung pengertian suatu arena atau tempat bertanding. Dengan demikian Gelanggang Remaja memiliki pengertian tempat bertanding atau berkompetisi para remaja dalam berbagai macam kegiatan. Sehubungan dengan itu maka Gelanggang Remaja juga dapat dipahami sebagai suatu arena atau tempat yang bersifat tetap bagi para remaja untuk menyelenggarakan berbagai macam kegiatan secara teratur dan terarah dengan penanggung jawab tertentu. Di dalam Youth Center mereka dapat berekreasi dan berkreasi sesuai dengan aspirasi, hasrat, bakat dan niatnya serta dapat menggunakan fasilitasi yang tersedia di tempat. Sehingga arena ini bermaksud memberikan fasilitas bagi penyaluran dan pengembangan aspirasi, hasrat dan minat yang kreatif dimana penyelenggaraannya berlandaskan pada unsurunsur pendidikan dan rekreasi.

Pasca pelatihan Kader Sebaya, kegiatankegiatan Youth Centre Kesehatan Reproduksi mulai dilaksanakan oleh Kader Sebaya. Kegiatan yang sudah dilakukan antara lain melakukan perkumpulan dan diskusi-diskusi terkait kesehatan reproduksi remaja yang disisipkan melalui kegiatan-kegiatan Karang Taruna agar efektif dalam pelaksanaannya. Berdasarkan hasil monitoring, kegiatan ini telah dilaksanakan di desa Singorojo. 
Setelah diberikan pelatihan Youth Centre Kesehatan Reproduksi, Kader Sebaya mulai mencoba melaksanakan edukasi kepada remaja sasaran melalui kegiatan Karang Taruna di desa Singorojo. Hasil edukasi sebaya tersebut telah dapat meningkatkan pengetahuan remaja khususnya terkait kesehatan reproduksi remaja, seksualitas dan kehamilan berisiko tinggi.

Tabel 2 menunjukkan, dari 29 orang remaja yang hadir dan mengikuti edukasi kesehatan reproduksi remaja, sebagian besar atau 21 orang remaja $(72,41 \%)$ masih memiliki pengetahuan yang kurang tentang kesehatan reproduksi remaja, dampak kehamilan usia remaja serta kehamilan berisiko tinggi. Selain itu, mereka juga tidak mengetahui faktor risiko terjadinya kehamilan risiko tinggi yang dapat dilihat dari usia hamil terlalu muda atau tua serta faktor risiko lainnya.

Fakta ini berubah secara signifikan setelah mereka diberikan edukasi sebaya kesehatan reproduksi melalui kegiatan-kegiatan diskusi oleh Kader Youth Centre, remaja yang pengetahuannya masih dalam kategori kurang jumlahnya berkurang menjadi 10 orang (34,48\%). Hal ini menunjukan terdapat peningkatan pengetahuan yang siginifikan antara sebelum dan sesudah dilaksanakannya edukasi sebaya kesehatan reproduksi ( $p$ value 0,001).

Youth Centre ini adalah salah satu program yang dikembangkan untuk upaya dalam menangani persoalan remaja maupun komunitasnya. Pendekatan yang dilakukan Youth Centre adalah dari, oleh dan untuk remaja. Youth Center ini merekrut remaja untuk diseleksi dan dilatih menjadi pendidik sebaya dan konselor sebaya selain itu Youth Centre ini sepenuhnya dikelola oleh remaja.
Hal ini telah sesuai dengan prinsip-prinsip pengembangan Youth Centre sebagai wadah layanan terhadap remaja, antara lain: 1) Remaja berhak mendapatkan informasi dan pelayanan kesehatan reproduksi yang lengkap dan tepat sesuai dengan kebutuhan mereka; 2) Remaja berhak dilibatkan dalam pelaksanaan program, mulai dari perencanaan, pelaksanaan, monitoring, dan evaluasi; 3) Remaja perlu memiliki sikap dan perilaku yang sehat dan bertanggung jawab berkenaan dengan kesehatan reproduksinya.

Youth Centre yang salah satu kegiatannya adalah memberikan edukasi sebaya telah mampu meningkatkan pengetahuan kesehatan reproduksi remaja sasaran di desa mitra. Hal ini sesuai dengan penelitian Savitri et al (2013) yang menyatakan ada pengaruh yang signifikan antara pemberian pendidikan kesehatan reproduksi terhadap tingkat pengetahuan tentang seks bebas pada remaja.

Hasil kegiatan ini juga menyatakan bahwa edukasi sebaya kesehatan reproduksi remaja melalui diskusi telah mampu meningkatkan pemahaman remaja tentang kesehatan reproduksi remaja di desa mitra. Hal ini juga sesuai dengan Suriani dan Hermansyah (2015) yang menyatakan bahwa penyampaian pendidikan kesehatan oleh peer group berpengaruh terhadap peningkatan pengetahuan remaja. Hal senada oleh Taukhit (2014), yang menyatakan pendidikan reproduksi pada remaja perlu disesuaikan dengan perkembangan pada remaja. Pada usia remaja dalam pembelajaran cenderung ingin tahu terhadap suatu hal. Metode pembelajaran yang lebih sesuai adalah dengan metode diskusi untuk menerima suatu kesimpulan dan tidak kaku secara penyampaian materi. Metode pembelajaran tersebut bertujuan

Tabel 2. Perbedaan Pengetahuan Remaja Sasaran antara Sebelum dan Sesudah Diterapkannya Program Youth Centre

\begin{tabular}{llcccc}
\hline \multirow{2}{*}{ Pengetahuan Remaja Sasaran } & \multicolumn{3}{c}{ Sesudah } & \multirow{2}{*}{$p$ value } \\
\cline { 3 - 5 } & & Kurang baik & Baik & Jumlah & \\
\hline Kebelum & Kurang baik & 10 & 11 & 21 & 0,001 \\
& Baik & 0 & 8 & 8 & \\
& Jumlah & 10 & 19 & 29 & \\
\hline
\end{tabular}


supaya pesan edukasi dapat diterima dan sesuai dengan tugas perkembangannya

Selain itu juga, remaja yang mengikuti edukasi kesehatan reproduksi remaja mulai lebih menyadari pentingnya pendewasaan usia perkawinan. Mereka mulai menyadari dampak kehamilan usia remaja.

Tabel 3 menunjukkan, sebelum dilaksanakan edukasi sebaya kesehatan reproduksi remaja diketahui masih banyak remaja sasaran yang memiiliki sikap kurang mendukung terhadap pendewasaan usia perkawinan. Dari 29 orang remaja yang hadir dan mengikuti edukasi kesehatan reproduksi remaja lebih dari separuh $(65,51 \%)$ memiliki sikap yang kurang mendukung terhadap pentingnya pendewasaan usia perkawinan.

Angka ini berubah secara signifikan setelah dilaksanakan edukasi sebaya kesehatan reproduksi remaja pada kelompok remaja sasaran. Hal ini ditunjukkan dengan penurunan persentase remaja yang kurang mendukung terhadap pendewasaan usia perkawinan pasca program Youth Centre diterapkan dan edukasi sebaya kesehatan reproduksi remaja dilaksanakan di desa mitra yaitu menjadi $31,03 \%$ ( $p$ value 0,002 ).

Sejalan dengan itu, seperti yang kita ketahui, dampak dari sikap negatif remaja dalam hal reproduksi adalah kehamilan di luar pranikah dan ingin menjalani aborsi. Remaja yang menjalani aborsi umumnya menyatakan bahwa sang pacarlah yang lebih dominan dalam menentukan keputusan aborsi, dengan alasan belum siap memasuki kehidupan perkawinan dan berkeluarga yang menuntut tanggung jawab besar, karena ingin melanjutkan sekolah atau kuliah, karena tidak ingin membuka aib keluarga dan mengecewakan orang tua, atau karena sang pacar lari dari tanggung jawab. Fakta ini menunjukkan bahwa dalam kasus aborsi, inisiatif yang dominan dalam pengambilan keputusan tentang tindak lanjut kehamilan terletak pada remaja laki-laki.

Sebagian besar remaja yang meneruskan kelahiran pada awalnya telah berusaha melakukan aborsi dengan cara-cara yang bervariasi. Ada yang sudah datang ke klinik kebidanan, dokter kandungan, atau PKBI, tetapi lalu ditolak karena tidak memenuhi syarat (seperti umur kandungan sudah terlalu tua untuk aborsi, tidak mampu menunjukkan surat nikah, atau dasannva kurang adekuat). Ada yang mencoba minum jamu atau ramuan tradisional pelancar haid; ada yang mencoba datang ke dukun paraji atau tukang urut tradisional; ada yang menenggak minuman keras dan obat-obatan tanpa resep dalam dosis tinggi. Setelah usaha-usaha itu gagal, mereka tidak punya pilihan lain kecuali meneruskan kehamilan. Sebagian besar responden yang gagal aborsi beruntung karena pasangannya mau bertanggung jawab menikahi, namun 20 persen sisanya terpaksa menjadi ibu dengan tidak menikah karena sang pacar lari dari tanggungjawab, atau karena orang tua remaja putri melarangnya menikah dengan laki-laki yang telah "merusak" kehidupan anak gadis mereka.

Orang pertama yang diberitahu tentang kehamilan rata-rata adalah pacar, dan reaksi awal kedua belah pihak pada umumnya adalah keinginan dan usaha untuk aborsi. Jika usaha aborsi gagal, barulah mereka berterus terang kepada orangtua. Diluar dugaan banyak responden, banyak orang tua yang ternyata, meskipun marah besar dan kecewa dapat tidak mendukung aborsi. Alasannya adalah nanti

Tabel 3. Perbedaan Sikap Remaja Sasaran antara Sebelum dan Sesudah Diterapkannya Program Youth Centre

\begin{tabular}{llllll}
\hline \multirow{2}{*}{ Sikap } & \multicolumn{2}{l}{ Sesudah } & \multicolumn{2}{c}{$p$ value } \\
\cline { 3 - 5 } & & Kurang Mendukung & Mendukung & Jumlah & \\
\hline Sebelum & Kurang mendukung & 9 & 10 & 19 & 0,002 \\
& Mendukung & 0 & 10 & 10 & \\
& Jumlah & 9 & 20 & 29 & \\
\hline
\end{tabular}


akan berdosa dua kali lipat bila melakukan aborsi. Orangtua remaja putri biasanya lalu memusyawarahkan masalah ini dengan pacar si puteri dan orang tuanya, dan jalan keluar yang diambil biasanya adalah menikahkan keduanya. Jadi, dapat dilihat bahwa ada tiga faktor yang berperanan penting dalam resolusi keputusan tindak lanjut kehamilan. Faktor pertama adalah sikap significant others, terutama sang pacar (meliputi intensitas hubungan dan peran gender) dan orang tua; faktor kedua adalah sikap terhadap aborsi dalam kaitannya dengan nilai-nilai normatif; dan faktor ketiga adalah pertimbangan konsekuensi sosial ekonomi.

Kehamilan remaja juga memunculkan konsekuensi psikologis yang cukup berat. Remaja hamil mengalami rasa rendah diri, malu, dan merasa bersalah karena telah melakukan tindakan yang dipandang sebagai aib dan dosa oleh norma-norma agama dan masyarakat (Amalia, 2017). Dalam beberapa kasus, remaja yang hamil bahkan nekat mengambil keputusan bunuh diri karena merasa sangat bersalah, helpless, depresi, bingung, dan frustrasi (Pakasi, 2013)

Selain itu, dari segi konsekuensi sosialekonomi, terjadi peningkatan jumlah anak-anak yang terbuang (abandoned) dan yang diperlakukan salah (abused) olehibuibuusiaremaja (WHO, 2001) Ketidakstabilan kehidupan rumah tangga, terputusnya sekolah (school leaving), masalah ekonomi, dan masalah pengasuh ananak adalah beberapa komplikasi lain yang disebabkan oleh kehamilan dini yang tak dikehendaki pada remaja (Arsani, 2013). Dalam ungkapan yang berbeda, Pakasi (2013) menyatakan bahwa kehamilan remaja akan berpengaruh negatif terhadap tingkat pendidikan yang dapat dicapai, posisi ekonomi di kemudian hari, dan partisipasi angkatan kerja perempuan.

Berbagai konsekuensi negatif tersebut tidak saja dialami oleh remaja perempuan yang bersangkutan, tetapi juga oleh pasangannya, bayi yang dikandung atau anak yang dilahirkannya, orang tua dan keluarga remaja yang bersangkutan, serta akhirnya oleh masyarakat secara keseluruhan jika masalahiniterjadi secara masif.

Remaja yang hamil berasal dari kelas sosial-ekonomi yang beragam, dengan jumlah terbesar berasal dari kelas menengah ke bawah. Pasangan yang menghamili umumnya berasal dari kelas sosial-ekonomi yang setara.

Konsekuensi sosial-ekonomi yang paling menonjol dari masalah kehamilan remaja adalah terputus atau tertundanya sekolah atau kuliah, meningkatnya ketergantungan finansial pada orangtua atau anggota keluarga lain, kesulitan mendapatkan pekerjaan yang sesuai dengan harapan, dan kesulitan memenuhi kebutuhan ekonomi secara mandiri.

Pendidikan kesehatan reproduksi sangat penting bagi remaja karena dapat meningkatkan pengetahuan dan sikap remaja agar mereka memiliki kesadaran dan tanggungjawab yang tinggi terhadap kesehatan reproduksinya. Hal ini sesuai dengan Sutajaya (2013), yang menyatakan bahwa pendidikan kesehatan reproduksi dan seksualitas memiliki tujuan utama untuk memberikan informasi kepada remaja untuk memberdayakan mereka dalam membangun nilai dan keterampilan berelasi yang memampukan mereka membuat keputusan yang bertanggung jawab untuk menjadi orang dewasa yang sehat secara seksual pendidikan kesehatan reproduksi dan seksual penting untuk di berikan.

Pendidikan kesehatan reproduksi remaja melalui program Youth Centre ini telah mampu meningkatkan kesadaran remaja akan pentingnya pendewasaan usia perkawinan. Mereka mulai menyadari bahwa perkawinan usia muda akan berdampak pada terjadinya kehamilan berisiko tinggi.

\section{PENUTUP}

Tanggapan masyarakat umum yang masih didominasi penolakan terhadap program program pendidikan kesehatan reproduksi untukrjemaja menyebabkan keragu-raguan di kalangan pengambil kebijakan untuk mengimplementasikan kebijakan kesehatan reproduksi untuk remaja yang sangat 
kontroversial ini. Sebagai contoh, setting sekolah belum dimanfaatkan sebagai wadah potensial untuk program-program prevensi kehamilan remaja. Hingga kini belum diterapkan kebijakan yang mengatur sekolah untuk menyediakan informasi mengenai topiktopik yang berkaitan dengan masalah seks dan kesehatan reproduksi, baik sebagai matapelajaran terpisah maupun sebagai bagian dari subjek pelajaran lain seperti biologi atau olah raga. Ceramah dan penyuluhan yang rutin biasanya hanya terbatas pada isu narkoba (Narkotik dan obat terlarang) dan penataran P4, yang keduanya tidak menyentuh masalah kesehatan reproduksi remaja.

Isu kehamilan remaja memang pada satu sisi memiliki dilema psikologis bagi berbagai kalangan masyarakat, kelompok profesional, dan para pengambil kebijakan. Akan tetapi, dilain sisi isu ini berkembang sangat cepat dalam intensitas yang menguatirkan sehingga membutuhkan penanganan programatik yang sungguh-sungguh Dalam kata-kata Dini (2016), diperlukan kerja sama multidisipliner dan interdepartemental untuk menemukan cara-cara efektif dalam mendorong remaja menjadi orang tua yang baik pada masa depan tanpa memacu mereka untuk menjadi orang tuadi usiadini; dan cara-carayangbijak untuk melindungi remaja dari konsekuensi negatif kehamilan dim tanpa menghukum mereka yang sudah terlanjur tergelincir

Hasil edukasi sebaya yang dilakukan oleh Kader Youth Centre yang telah diberi pelatihan telah mampu meningkatkan pengetahuan remaja di desa mitra khususnya terkait kesehatan reproduksi remaja, seksualitas dan kehamilan berisiko tinggi. Selain itu juga, dapat meningkatkan kesadaran remaja akan pentingnya pendewasaan usia perkawinan. Sehingga terhindarnya adanya kehamilan di luar nikah, dan akhirnya berujung ke aborsi, yang tentunya mengurangi resiko adanya kematian.

Youth Centre dapat menjadi sarana dalam peningkatan pengetahuan dan sikap remaja terkait permasalahan kesehatan reproduksi remaja serta sebagai upaya pencegahan kehamilan pada usia remaja yaitu dengan pendewasaan usia perkawinan. Oleh karena itu, program dan kegiatan Youth Centre ini harus mendapatkan dukungan dari berbagai pihak khususnya pemerintah desa, stakeholder kesehatan dan para remaja agar tujuan Youth Centre dalam ikut serta menurunkan faktor risiko terjadinya kehamilan risiko tinggi khususnya di daerah pedesaan dapat tercapai.

\section{DAFTAR PUSTAKA}

Aeni. Nurul. 2012. Perilaku Kesehatan Ibu Hamil di Kabupaten Pati (Studi Pada Kasus Kematian Maternal Tahun 2011). Jurnal Litbang. 8 (3): 200-207.

Aeni. Nurul. 2013. Risk Factors of Maternal Mortality. Kesmas (Jurnal Kesehatan Masyarakat Nasional). 7(10) : 453-459.

Amalia, E. H., \& Azinar, M. 2017. Kehamilan Tidak Diinginkan pada Remaja. HIGEIA (Journal of Public Health Research and Development), 1(1): 17.

Arsani, N. L. K. A. (2013). Peranan program PKPR (Pelayanan Kesehatan Peduli Remaja) Terhadap Kesehatan Reproduksi Remaja di Kecamatan Buleleng. Jurnal Ilmu Sosial dan Humaniora, 2(1).

Bazaar A. Theodorus and A. Azhari. Maternal Mortality and Contributing Risk Factors. Indonesian Journal of Obstetric and Gynecology. 36 (1): 8-13.

Buzarudina, F. 2013. Efektivitas Penyuluhan Kesehatan Reproduksi Remaja Terhadap Tingkat Pengetahuan Siswa Sman 6 Kecamatan Pontianak Timur Tahun 2013. Jurnal Mahasiswa PSPD FK Universitas Tanjungpura, 3(1).

Dini, L. I., Riono, P., \& Sulistiyowati, N. (2016). Pengaruh Status Kehamilan Tidak Diinginkan Terhadap Perilaku Ibu Selama Kehamilan dan Setelah Kelahiran di Indonesia (Analisis Data SDKI 2012). Jurnal Kesehatan Reproduksi, 7(2): 119-133.

Dinkes Jateng. 2017. Profil Kesehatan Jawa Tengah Tahun 2016. Semarang: Dinkes Jateng.

Dinkes Kendal. 2018. Laporan Data Kematian Ibu Tahun 2017. Kendal: Dinkes Kendal.

Gutierrez. R. Gustavo. Vera.E. de Lean P. Vargas LF. 2007. Risk Factors of Maternal Death in Mexico. Birth. Vol 34 : 21-25. 
Kaddour C. Souissi R. Haddad Z. Zaghdoudi. Magouri M. Saussi M. et al. 2008. Causes and Risk Factors of Maternal Mortality in the ICU. Critical Care. Volume 12 suppl 2 pp. 492.

Karlsen et.al.. 2011. The Relationship between Maternal Education and Mortality among Women Giving Birth in Health Care Instituttions: Analysis of the cross sectional WHO Global Survey on Maternal and Perinatal Health. BMC Public Health. Vol 11.

Pakasi, D. T., \& Kartikawati, R. 2013. Antara kebutuhan dan tabu: pendidikan seksualitas dan kesehatan reproduksi bagi remaja di SMA. Jurnal Makara Seri Kesehatan, 2(17): 79 81.

Pratitis. Dian dan Kamidah. 2013. Hubungan antara Pengetahuan Ibu Hamil tentang Tanda Bahaya Kehamilan dengan Kepatuhan Pemeriksaan Kehamilan di BPS Ernawati Boyolali. GASTER. (10)2: 33-41.

Savitri, Dian; Kirnantoro, Nurunniyah, Siti. 2013. Pemberian Pendidikan Kesehatan Reproduksi Berpengaruh Terhadap Tingkat Pengetahuan
Tentang Seks Bebas pada Remaja Kelas X dan XI 2 di SMK Muhammadiyah II Bantul. Jurnal Ners dan Kebidanan Indonesia (JNKI). 1(1): 23-28.

Suriani dan Hermansyah. 2015. Pengaruh Peer Group terhadap Peningkatan Pengetahuan Kesehatan Reproduksi Remaja. Jurnal Ilmu Keperawatan. 22-27.

Sutajaya, I. M. (2013). Perbaikan Kondisi Kerja Berbasis Kearifan Lokal yang Relevan dengan Konsep Ergonomi untuk Meningkatkan Kualitas Kesehatan dan Produktivitas Pematung. Jurnal Ilmu Sosial dan Humaniora, 2(1).

Taukhit. 2014. Pengembangan Edukasi Kesehatan Reproduksi dan Seksualitas Remaja dengan Metode Game Kognitif Proaktif. Jurnal Studi Pemuda. 3(2): 123:131.

WHO. 2001. Maternal Mortality Surveillance. WHO : Training Course on Using Data for Decesion Making. 